\title{
MENGEMBANGKAN POTENSI JAMU MELALUI DESA WISATA JAMU DAN PANGAN KREATIF
}

\author{
${ }^{1}$ Thathit Manon Andini, ${ }^{2}$ Aini Alifatin, ${ }^{3}$ Dini Kurniawati, ${ }^{4}$ Nurhayatin, \\ ${ }^{5}$ Wildan Suharso, ${ }^{6}$ Anisatu Thoyyibah \\ 1.2.3.4.5,6 Universitas Muhammadiyah Malang \\ thathit@umm.ac.id
}

\begin{abstract}
Karangrejo Village, Kromengan Subdistrict, Malang Regency, which is well known as a producer of herbal medicine know as 'Jamu Gendong' since 1983 with 150 sellers of jamu Gendong incorporated in the Jamu Gendong Association of Karangrejo village, is still carrying out traditional production and marketing processes by carrying it around and going out of the area. In line with Permenkes No 3/2010 policy on herbal medicine scientification in research based on health services, which aims to increase the use of herbal medicine in health services through scientific research, as well as marketing activities that are very time-consuming and low production development, making Karangrejo village together with UMM Community Service Team, sparked Karangrejo Village as a Herbal Tourism and Creative Food Village. The approach method is aimed at 3 (three) main groups supporting the village economy, namely Village-owned business entity (BUMDes), tourism aware groups (POKDARWIS) and herbal medicine group POKJAMU, which include: Community facilitation models in the form of training and enhancing the quality of partner resources related to strengthening and fostering the structure and function of the organization, in the form of setting Vision, Mission, Logo, AD / ART to short and long term work plans. While assistance in the framework of production processing, packaging, marketing, diversification of processed products is carried out in order to improve production quality. Cooperation with the Department of food crop, Hortikultura and plantations in the procurement of ginger and turmeric seeds is aimed at reforesting the medicinal education tourism area. The construction of the Archway, the zero point tourism monuments and publications are carried out through weblogs, online and print publications.
\end{abstract}

Keywords: Tourist Village, Herbal Medicine, Creative Food, Education

\section{PENDAHULUAN}

Desa Karangrejo lebih dikenal dengan desa jamu gendong, karena terdapat sekitar 150 keluarga yang memproduksi jamu sekaligus sebagai menjadi penjual jamu gendong dan disepanjang jalan dan pekarangan rumah juga terdapat tanaman herbal dan bahan jamu. 

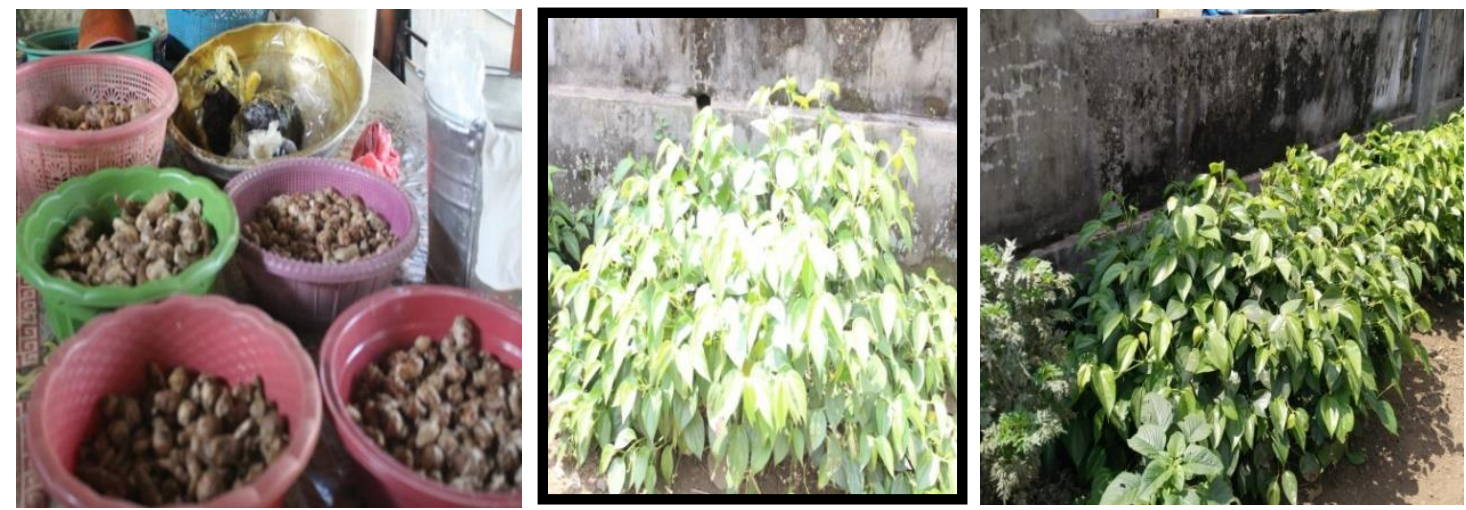

Gambar 1: bahan obat yang mudah diperoleh di pekarangan desa Karangrejo

Hasil jamu ini sangat istimewa karena hasil produksinya yang nikmat, lebih tahan lama meskipun tanpa pengawet, namun untuk mendapatkan hasil produk jamu yang memuaskan ini memerlukan waktu, dan tenaga yang banyak. Proses produksi yang masih menggunakan peralatan tradisional menyebabkan hasil produksi terbatas omsetnya. Belum lagi persoalan pemasaran, juga menjadi kendala yang besar. Dalam proses pemasaran, masih terbatas dilakukan di daerah sekitar Desa hingga sekitar Kabupaten Malang. Meskipun terdapat kurang lebih 150 keluarga yang memproduksi jamu, namun penjualan masih dilakukan secara sporadis, secara terpisah-pisah dan tidak terkoordinir. Setiap pagi hari Ibu-ibu penjual jamu menjajakan jamunya dengan cara diangkut bersama dan didrop di titik-titik tertentu di luar desa Karangrejo maupun di luar kabupaten Malang seperti Malang, Blitar, Trenggalek dan baru pulang pada sore atau malam hari.
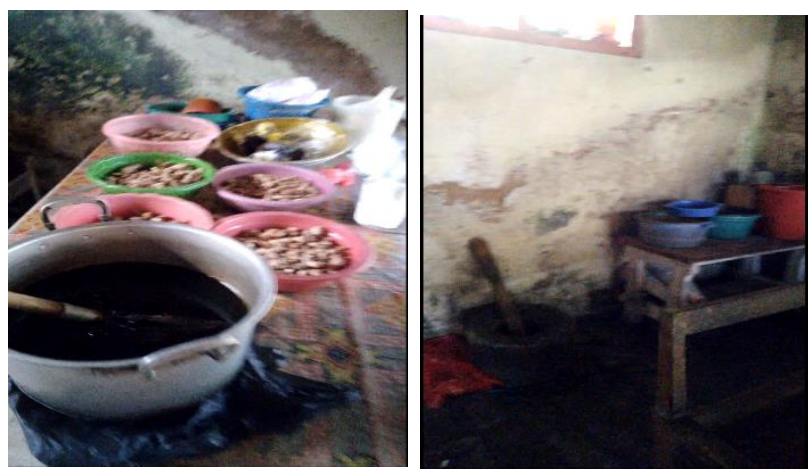

Gambar 2: Proses pengolahan jamu yang masih konvensional dengan kemasan daur ulang

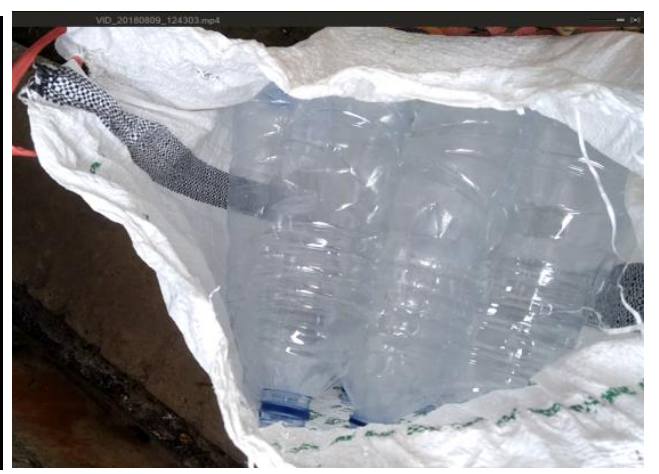
g

Aktifitas pembuatan jamu ini sebenarnya sudah turun temurun dilakukan, namun proses pengolahan dan pemasaran yang masih dilakukan secara konvensional dengan cara digendong dan berkeliling sedemikian rupa sangat menyita waktu dan tidak dapat focus pada pengembangan produksi. Saat ini setiap hari, produksi pedagang bisa mencapai 8 - 13 botol ukuran 1,3 liter, dan mendapatkan penghasilan kotor kurang lebih 150 ribu dari pagi hingga malam hari. Namun proses pembuatan yang lama, penjualan yang harus ditempuh dengan jarak dan waktu yang jauh, memungkinkan produktifitas dan kinerja pedagang sangat tidak proporsional dengan penghasilan yang 
diperoleh. Proses pengemasan yang masih menggunakan daur ulang serta pemasaran terbatas hanya bertahan selama 3-5 hari. Oleh karenanya desa Karangrejo bermaksud untuk memberdayakan dan meningkatkankan produktifitas "bakul Jamu" sehingga meningkat pula kesejahteraan warga dan produk jamu sebagai Produk Unggulan Desa.

\section{Permasalahan prioritas}

Permasalahan yang ada di desa Karangrejo ini, adalah banyak potensi yang bisa dikembangkan, namun masih rendahnya kwalitas SDM dan sarana prasarana yang belum mendukung, serta minat dan bakat masyarakat untuk menjadikan desa wisata masih rendah. Oleh karenanya pemerintah desa bersama Universitas Muhammadiyah Malang menyepakati bahwa yang menjadi prioritas dari masalah yang akan diperbaiki adalah

\section{a. Sumber daya alam dan sarana prasarana}

- Tersedianya bahan baku herbal yang melimpah ( jamu dan tanaman produktif lainnya seperti pisang,ketela dll) ,namun masih belum dioptimalkan dengan baik

- Belum terfikirkan tentang pelestarian / reboisasi sumber bahan baku herbal yang bisa habis setiap waktu

- Lahan desa yang luas dan indah didukung potensi alam yang melimpah dan SDM yang handal dalam meracik dan menghasilkan jamu memerlukan upaya untuk menjadikan desa sebagai desa wisata jamu dan pangan kreatif

- Sudah terdapat unit-unit usaha namun masih terbatasnya peralatan produksi yang menyebabkan usaha produksi dilakukan secara konvensional

- Peralatan produksi yang masih tradisional ( penumbuk jamu dengan "lumpang dan Alu", dan lingkungan yang kurang higienis, memerlukan pendampingan untuk produksi yang aman dan jumlah yang tinggi

\section{b. Sumber daya manusia}

- SDM yang handal dalam meracik dan menghasilkan jamu serta pangan kreatif namun konvensional dalam pengelolaan, produksi dan pemasaran

- Terbatasnya kemampuan kreasi produk jamu dalam kemasan yang berbeda dan dalam bentuk yang berbeda seperti, permen jamu, es cream, es jamu serta pangan kreatif lainnya

- Belum optimalnya pemberdayaan Kelompok PKK, Pemuda dan usia produktif

- Organisasi mitra yang belum terbentuk baik terkait dengan produksi maupun tentang desa wisata, dan pengetahuan tentang Manajemen organisasi, keuangan, pembagian tugas dan lain-lain yang belum belum pernah dipelajari

Berdasarkan latar belakang inilah pemerintah desa Karangrejo secara sungguhsungguh berupaya untuk membangun perekonomian baru bagi warga dengan bekerja sama dengan pihak Universitas Muhammadiyah Malang, guna menciptakan tambahan lapangan pekerjaan dan peningkatan produksi sesuai potensi yang ada melalui Program Pembangunan Desa Mitra (PPDM) Desa Wisata Jamu dan Pangan kreatif.

\section{METODE}

Metode pendekatan yang dilakukan terhadap Kelompok mitra diantaranya adalah: 1) Model pendampingan masyarakat berupa pelatihan dan peningkatan kualitas sumber daya mitra dalam rangka produksi pengolahan, pengemasan, pemasaran, 2). Workshop tentang pengolahan jamu instan berbentuk serbuk dan pengolahan pangan kreatif, 3). Model tindak lanjut yang lebih ditekankan pada pendampingan SDM sebagai persiapan menjadi desa wisata, diantaranya perumusan 
kembali Visi, Misi, Renstra, s/d SOP baik pada BUMDes, POKDARWIS maupun POKJAMU 4) Metode pendekatan dan publikasi berupa pembuatan web dan pembuatan Monument Jamu Gendong sebagai pintu gerbang selamat datang di kawasan Desa Wisata Jamu Dan Pangan Kreatif.

Kegiatan pengabdian direncanakan dilakukan selama tiga tahun berturut-turut, dengan kegiatan yang sudah terlaksana tahun pertama sebagai berikut :

\begin{tabular}{|c|c|c|c|c|c|c|c|c|c|c|c|}
\hline \multirow{2}{*}{ KEGIATAN PENDAMPINGAN } & \multicolumn{11}{|c|}{ WAKTU PELAKSANAAN } \\
\hline & 1 & 2 & 3 & 4 & 5 & 6 & 7 & 8 & 9 & 10 & 11 \\
\hline \multicolumn{12}{|l|}{$\begin{array}{l}\text { 1. Pertemuan dengan pengurus dan anggota } \\
\text { mitra untuk menjelaskan program dan } \\
\text { rencana pembinaan yang akan dilakukan. }\end{array}$} \\
\hline $\begin{array}{l}\text { 2. Study banding pengelolaan desa wisata } \\
\text { sebagai bahan refferensi pengembangan }\end{array}$ & & & & & & & & & & & \\
\hline $\begin{array}{l}\text { 3. Pendampingan organisasi dan manajemen } \\
\text { usaha mitra; BUMDes,POKDARWIS dan }\end{array}$ & & & & & & & & & & & \\
\hline $\begin{array}{l}\text { POKJAMU } \\
\text { 4. Pembuatan website untuk konsep }\end{array}$ & & & & & & & & & & & \\
\hline $\begin{array}{l}\text { pengembangan jamu dan pangan kreatif } \\
\text { (kripik-kripik) berbasis masyarkat.. }\end{array}$ & & & & & & & & & & & \\
\hline $\begin{array}{l}\text { 5. Pelatihan dan bimbingan teknis produksi dan } \\
\text { pengembangan produk jamu dan pangan } \\
\text { kreatif (kripik-kripik). }\end{array}$ & & & & & & & & & & & \\
\hline $\begin{array}{l}\text { 6. Pelatihan dan pendampingan pembuatan } \\
\text { jamu dan pangan berpotensi sebagai produk }\end{array}$ & & & & & & & & & & & \\
\hline $\begin{array}{l}\text { unggulan menjadikan desa wisata jamu dan } \\
\text { pangan kreatif (kripik-kripik) }\end{array}$ & & & & & & & & & & & \\
\hline $\begin{array}{l}\text { 7. Pembuatan Gapura Selamat Datang Desa } \\
\text { Wisata Jamu dan Pangan Kreatif. }\end{array}$ & & & & & & & & & & & \\
\hline $\begin{array}{l}\text { 8. Pengembangan Desain Monumen Jamu } \\
\text { dan desain Desa Wisata Jamu dan } \\
\text { Pangan Kreatif }\end{array}$ & & & & & & & & & & & \\
\hline
\end{tabular}

\section{HASIL KARYA UTAMA DAN PEMBAHASAN}

Untuk mewujudkan Desa Wisata Jamu dan pangan kreatif, diperlukan beberapa kegiatan awal dan berkelanjutan. Hasil dari upaya tim pengabdian UMM kerjasama dengan desa mitra adalah sebagai berikut :

A. Pemberdayaan organisasi dan manajemen usaha Desa Mitra untuk menumbuhkan kesadaran dan partisipasi anggota mitra akan peran pentingnya organisasi mitra dalam menciptakan peluang usaha dan peningkatan pendapatan desa

1) Studi banding ke café sawah desa wisata pujon kidul

Kafe sawah adalah suatu kawasan di desa pujon kidul yang sudah berhasil membangkitkan perkembangan desa menjadi desa wisata alam yang dapat menjadi inspirasi bagi aparat desa dan pengurus yang ditunjuk dalamrangkapersiapan desa wisata jamu. Studi banding ini diikuti oleh perwakilan desa, dan calon-calonpengurus Bumdes dan para pemuda desa yang diharapkan akan menjadi pembelajaran dalam rangka mempersiapkan diri menjadi desa wisata jamu. Peserta studi banding ditunjuk oleh kepala desa dengan mempertimbangkan masukan dari tim pengabdi UMM, sehingga diperoleh peserta yang benar-benar serius belajar dari keberhasilan desa pujon 
kidul dalam membawa kawasan tersebut sebagai desa wisata melalui café sawah.

Hasil studi banding berupa informasi tentang proses pembentukan Bumdes, pengelolaan café sawah,pengembangan café, sampai pada pengelolaan dan pengembangan asset sekitar desa berupa surat keputusan desa.
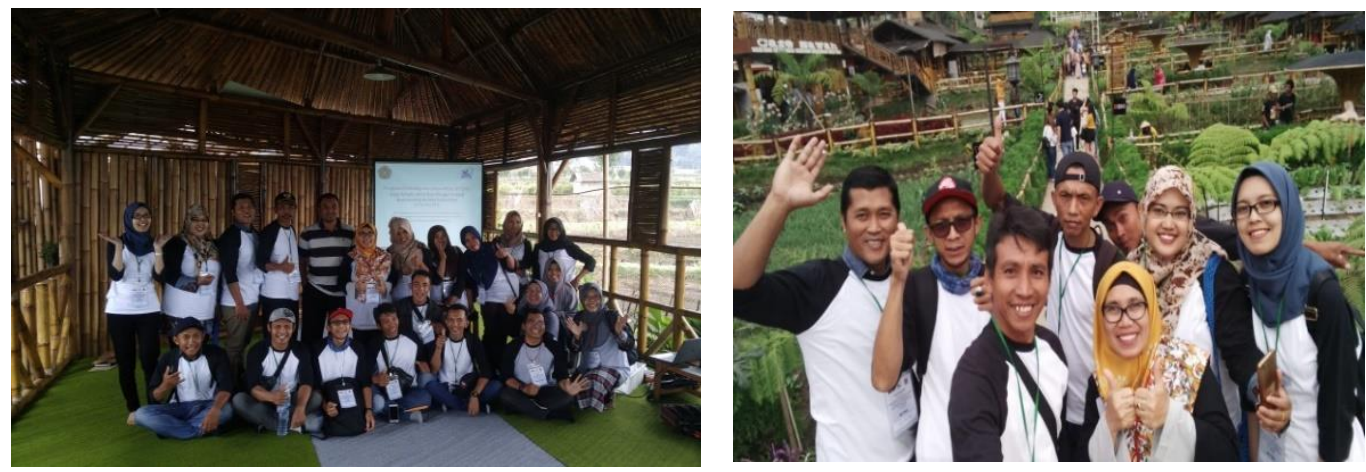

Gambar 3: Studi banding ke Pujon Kidul sebagai desa wisata

2) Pertemuan dengan pengurus dan anggota mitra untuk menjelaskan program dan rencana pembinaan yang akan dilakukan.

Hasil pertemuan disepakati bahwa ditahun pertama, akan dilakukan pemenuhan sarana penunjang untuk terbentuknya desa wisata berupa gerbang selamat datang, dan monument titik nol desa wisata. Selain itu ditetapkan untuk memberikan pembinaan berupa pelatihan bagi bakul jamu melalui pembentukan kelompok kecil yang didasarkan pada hasil pemetaan bersama ketua PKK dan tim pengabdian UMM. Dari hasil pemetaan ditetapkan 13 kelompok kecil yang merupakan perwakilan dari RT/RW setempat yang diharapkan menjadi isnpirator bagi bakul jamu lainnya yang belum teridentifikasi.

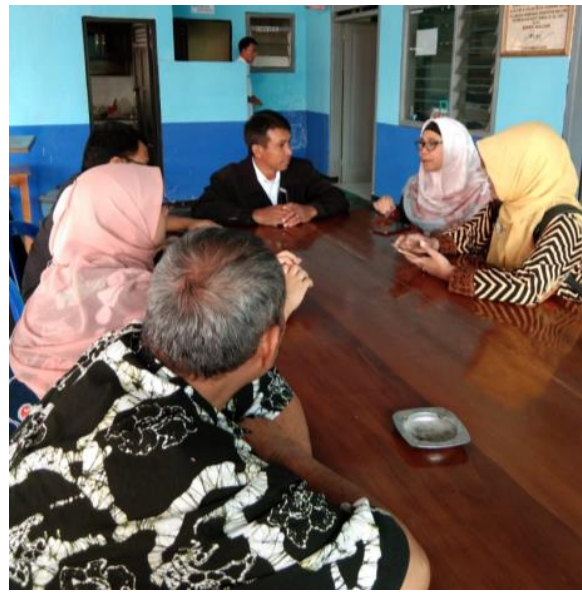

Gambar 4: proses diskusi yang menghasilkan kesepakatan kegiatan Pendampingan dan Pembinaan BUMDes, POKDARWIS dan POKJAMU 
B. Pemetaan Area titik wisata desa jamu dan pangan kreatif

Penetapan titik wisata terletak di dusun Blado, pada tanah bengkok pemerintahan desa Karangrejo,proses penetapan memerlukan pemotretan dengan menggunakan Drone sehingga diperoleh batasan yang jelas atas wilayah wisata.
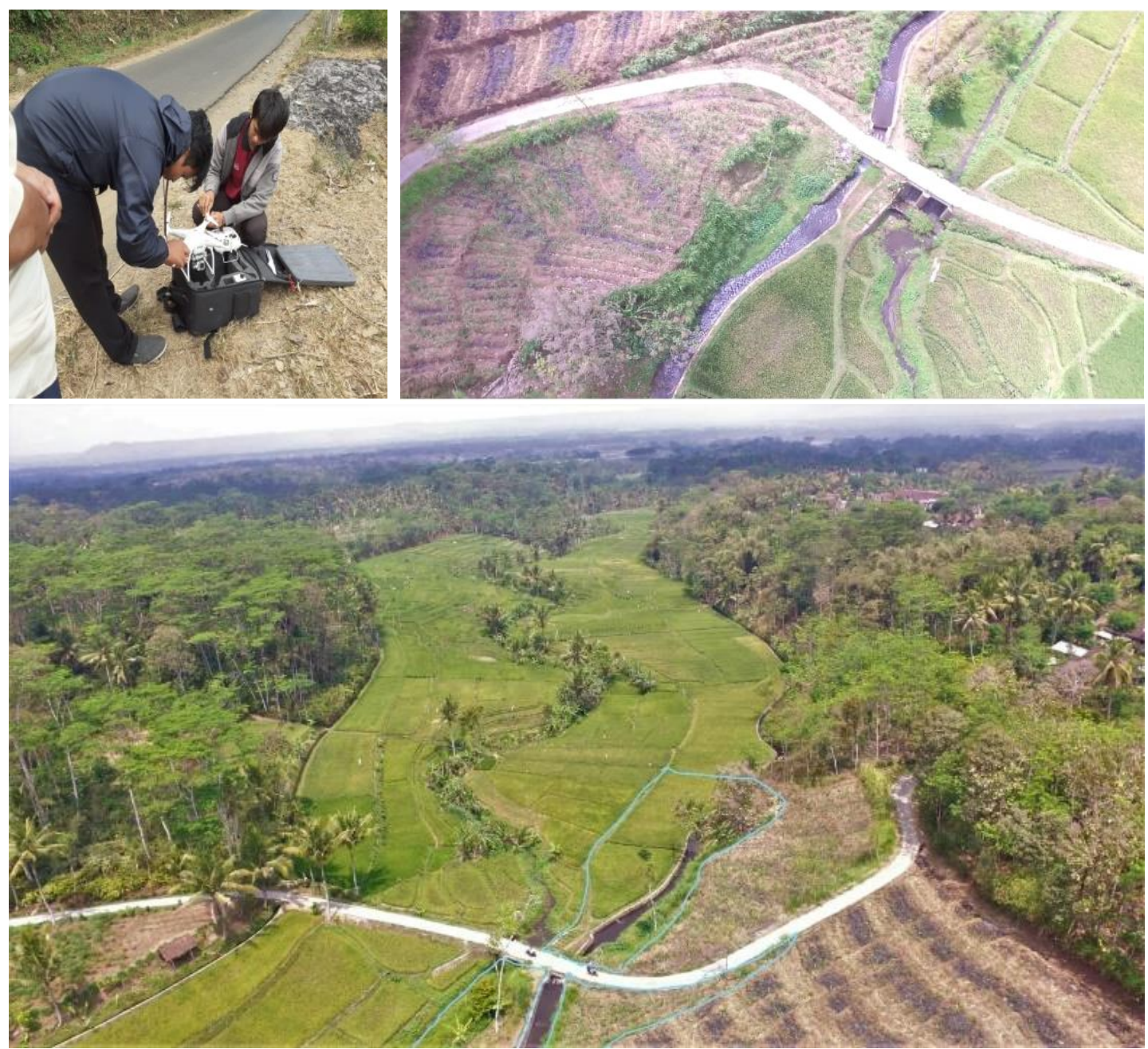

Gambar 5: titik nol desa wisata di dusun blado karangrejo

\section{Penanaman Toga kembali}

Sebagai symbol desa jamu, maka desa Karangrejo harus menghidupkan kembali penanaman toga di pekarangan rumah masing-masing warga. Kegiatan ini didukung oleh keputusan kepala desa untuk menggiatkan kembali penanaman toga dengan diberikan bantuan berupa polybag dan bibit kunyit,kencur,jahe dan toga lainnya.
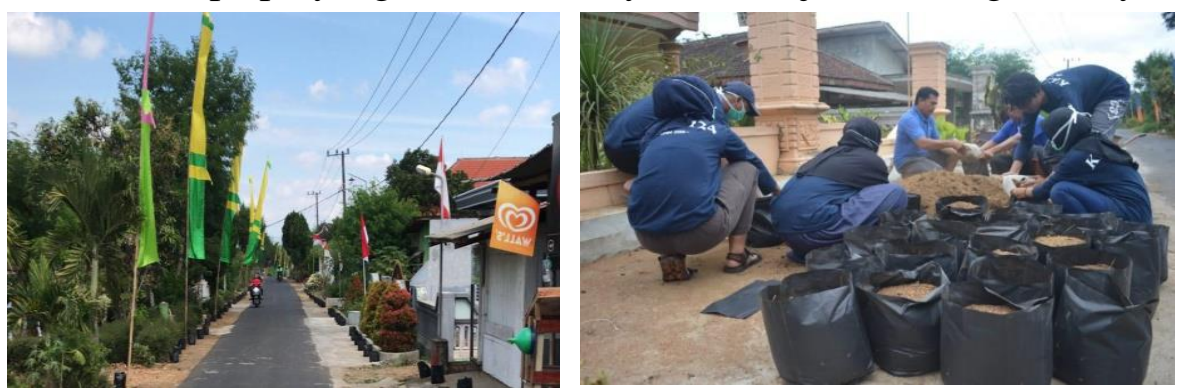

Gambar 6: aktifitas penanaman kembali toga oleh mahasiswa KKN bersama tim pengabdian UMM 
D. Perencanaan pembangunan gerbang selamat datang dan monument titik nol kawasan wisata

1) Gambaran pintu gerbang sebelum dan sesudahnya adalah sebagai berikut :
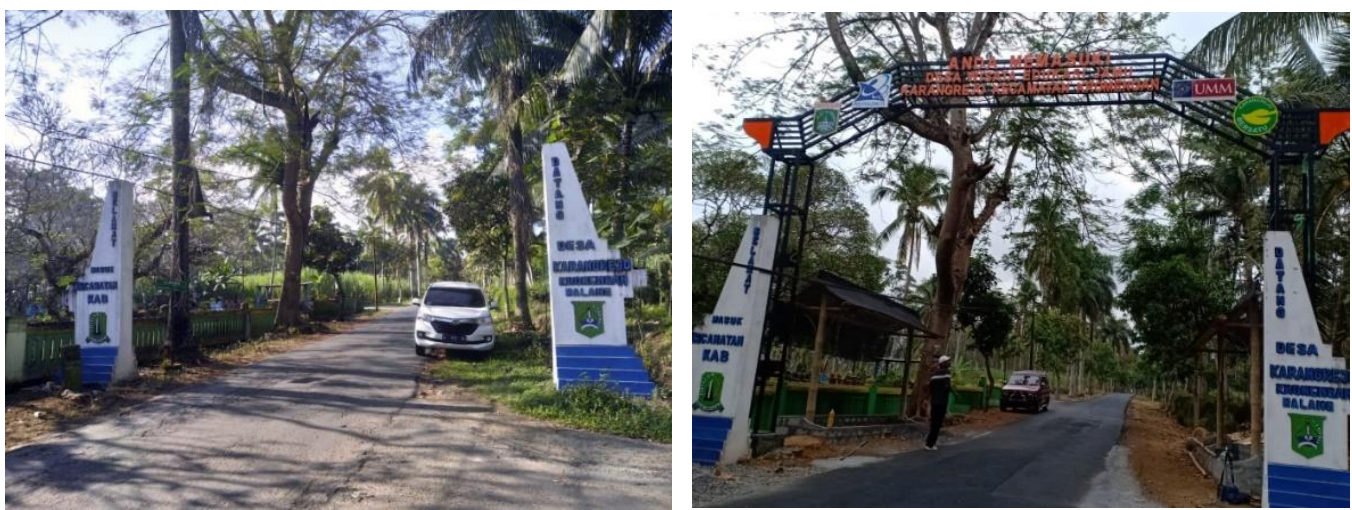

Gambar 7: proses pembangun gapura before dan after

Proses perancangan dan pengerjaan pintu gerbang selamat datang ini memerlukan waktu yang cukup lama. Perlu pengukuran yang jelas tentang ketinggian lengkung gapura mengingat juga terdapat kendaraan besar yang melintasi pintu masuk tersebut. Disamping kiri kanan bagian dalam gapura ditambahkan taman kecil guna mempercatik sambutan bagi para pengunjung desa wisata. Proses pembangunan ini masih terus berlangsung dikarenakan untuk mengupayakan taman masih menunggu adanya turun hujan.
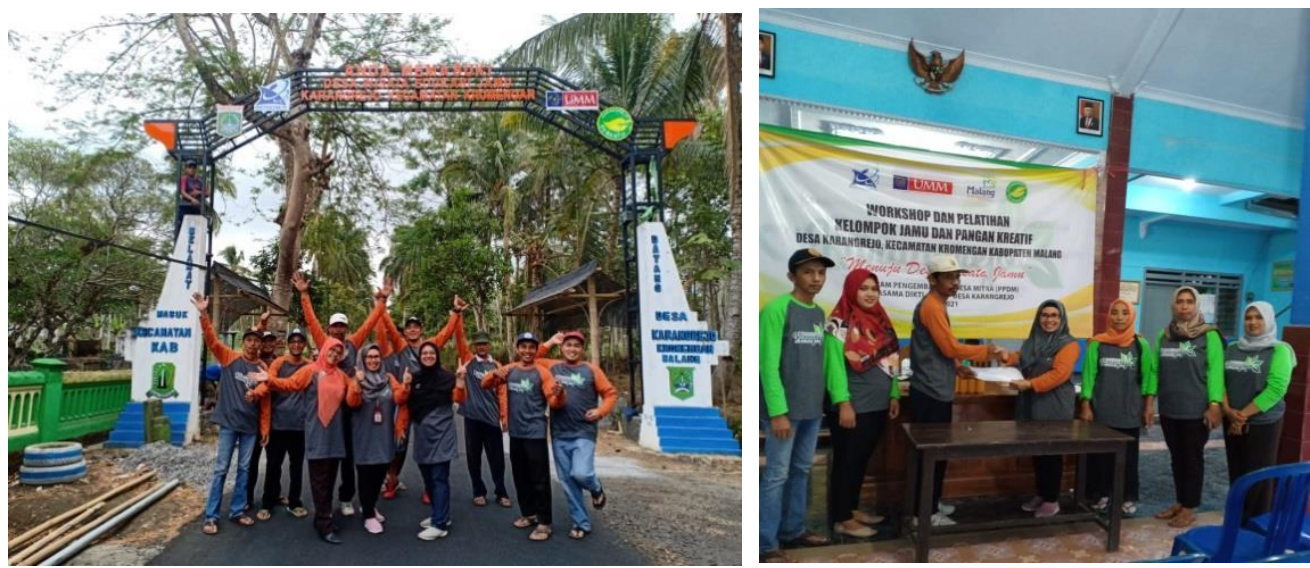

Gambar 8: finishing gapura ditandai dengan serah terima kepada kepala desa

2) Penetapan dan Desain titik Nol desa wisata

Demikian pula pengembangan titik nol wisata, setelah pemotretan dengan menggunakan Drone, saat ini masih dilakukan perencanaan desain dan menunggu hujan untuk persiapan tahap awal proses reboisasi tanaman herbal. Kawasan titik nol ini berasal dari tanah bengkok desa yang sebelumnya disewakan untuk pertanian tebu. Selanjutnya kawasan ini akan dikembangkan sebagai wisata edukasi jamu dimana di dalamnya terdapat area tanaman jamu, pusat-pusat kajian tentang tanaman herbal, café, gazebo-gazebo yang menyajikan berbagai produk jamu baik jamu segar maupun instan serta semua hasil diversifikasinya. Rencana ini diharapkan akan meningkatkan kesejahteraan masyarakat karena akan meningkatkan pengunjung dari berbagai 
wilayah,sehingga tidak diperlukan lagi harus mobile ke luar desa karangrejo untuk menjual jamunya.Di bawah ini adalah rancangan sementara lokasi titik nol sebagai bagian dari desain yang masih akan disempurnakan lagi.

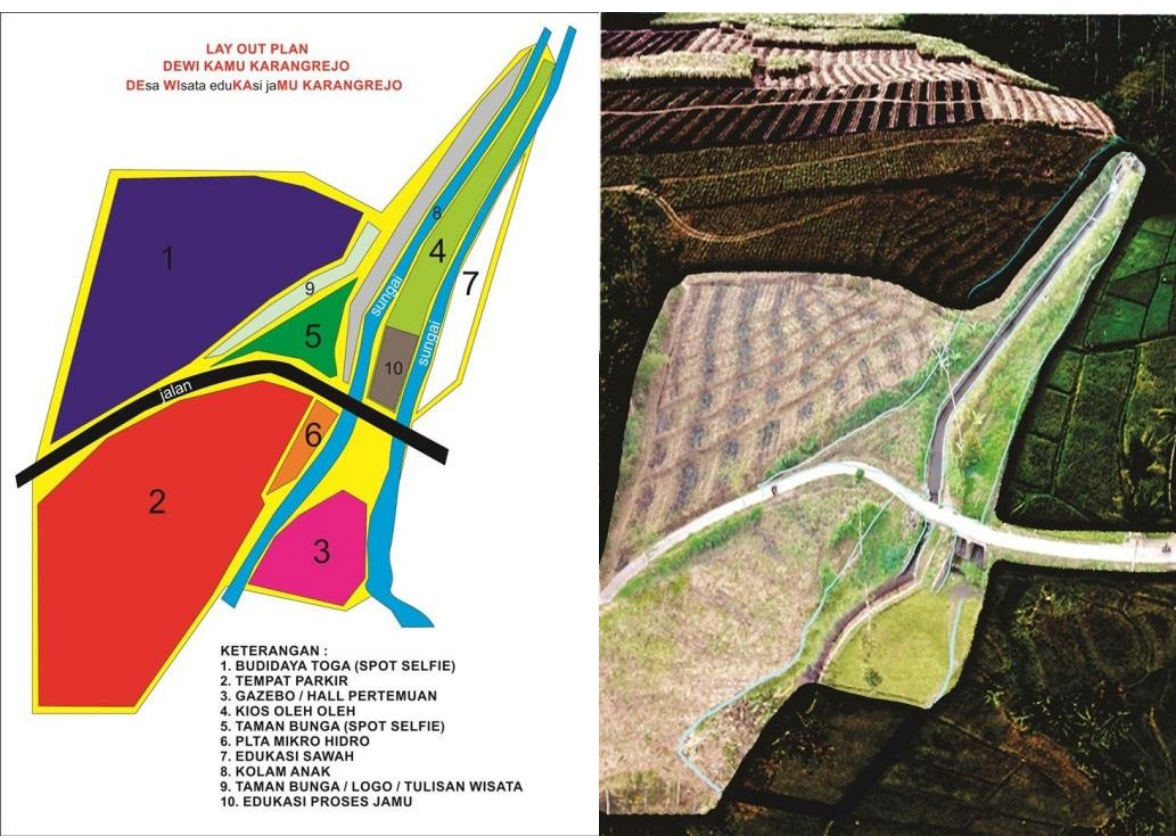

Gambar 9: desain lokasi titik nol wisata dusun Blado Karangrejo

Saat ini sudah dilakukan sosialisasi tentang penetapan lokasi wisata berdasarkan Perdes no 6/2019, dan sudah terpasang Baliho sebagai penanda akan dibangunnya area wisata tersebut. Pembangunan masih memerlukan dana yang besar dan desa Karangrejo sudah menyiapkan anggaran tersebut untuk tahun ke dua.

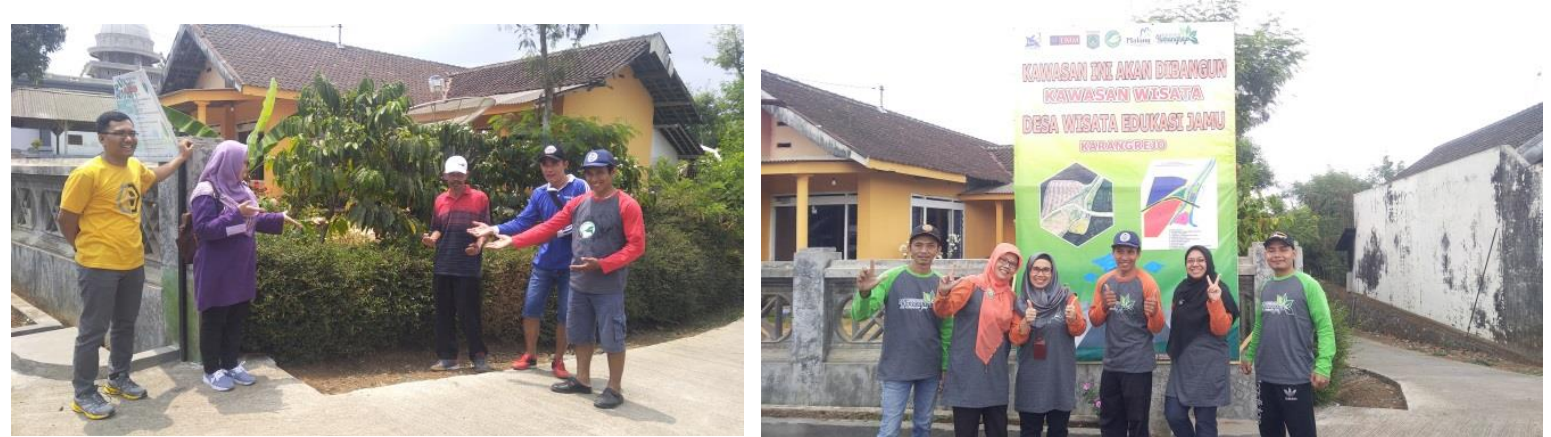

\section{Gambar 10: area titik nol yang akan dibangun monumen wisata jamu}

Area pada gambar di atas merupakan pintu masuk area wisata yang akan dibangun monumen jamu sebagai penanda titiknol wisata. Proses pengerjaan masih memerlukan waktu dan pendanaan yang tidak bisa dibilang sedikit.

E. Pendampingan organisasi dan manajemen usaha mitra; BUMDes,POKDARWIS dan POKJAMU

Proses berdirinya desa wisata memang tidak semudah impian. Namun berbekal mimpi proses pendirian bisa direalisasi. Proses pendirian desa wisata jamu di karangrejo diawali dengan lokakarya pembentukan kembali pengurus BUMDes yang sebelumnya belum aktif dan belum merumuskan visi,misi, tujuan dan rencana kegiatan. Proses lokakarya pendampingan dilakukan selama 4 kali pertemuan pada tiap-tiap organisasi, untuk bersama-sama merumuskan Visi, Misi sampai rencana kegiatan, disertai pembuatan logo BUMDes, POKDARWIS dan 
POKJAMU Karangrejo. Saat ini sedang berlagsung proses pengerjaan Standard Operasional Prosedur (SOP) baik dalamorganisasi BUMDes, maupun POKDARWIS. Penyusunan SOP mengacu pada visi, misi organisasi dan visimisi desa,agar terjadi sinergi dan
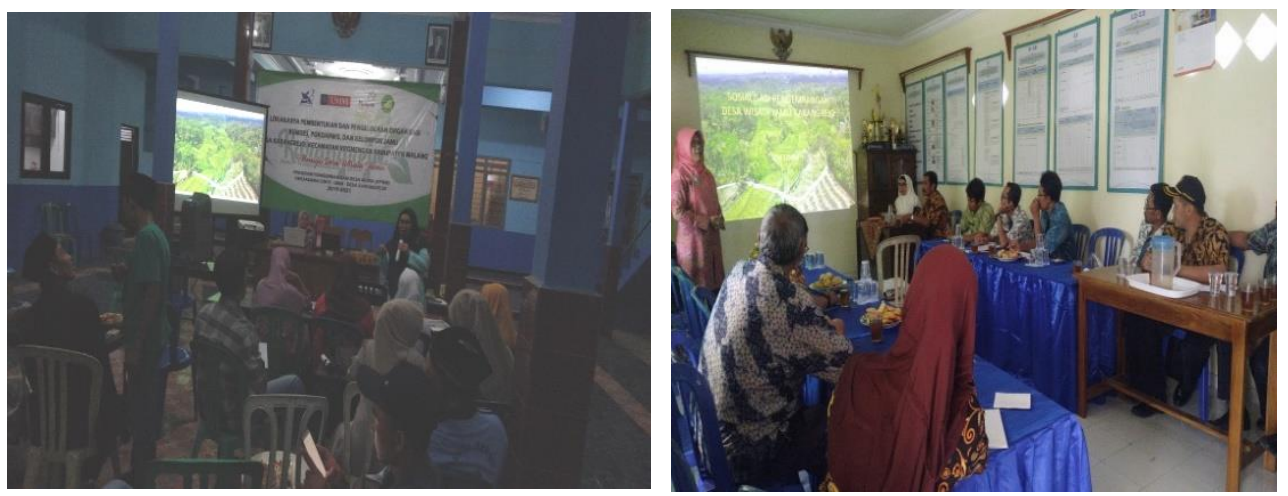

\section{Gambar 11: Proses Pendampingan Dan Pembinaan BUMDes, POKDARWIS dan POKJAMU}

setiap pertemuan disepakati waktu dengan peserta mengingat jadual yang padat sehingga tidak menutup kemungkinan pertemuan dilakukan malam hari.

F. Pelatihan dan bimbingan teknis produksi dan pengembangan produk jamu dan pangan kreatif.

Aktifitas pembuatan jamu yang sebenarnya sudah turun temurun dilakukan oleh kurang lebih 150 pengrajin sekaligus penjual jamu, namun proses pengolahan yang dilakukan belum menjamin kualitas produksi dan higienitas. Saat ini setiap hari, produksi pedagang bisa mencapai $8-13$ botol ukuran 1,5 liter, dan mendapatkan penghasilan kotor kurang lebih 150 ribu dari pagi hingga malam hari. Namun proses pembuatan yang lama, memungkinkan produktifitas dan kinerja pedagang sangat tidak proporsional dengan penghasilan yang diperoleh. Proses pengemasan yang masih menggunakan daur ulang serta pemasaran terbatas hanya bertahan selama 3-5 hari. Oleh karenanya pendampingan yang dilakukan oleh Tim Pengabdian UMM lebih awal menitik beratkan pada proses produksi yang higienis dan pemahaman tentang pengemasan yang aman dan bukan daur ulang. Kegiatan ini dimaksudkan untuk memberdayakan dan meningkatkankan produktifitas "bakul Jamu" sehingga meningkat pula kesejahteraan warga dan produk jamu sebagai Produk Unggulan Desa
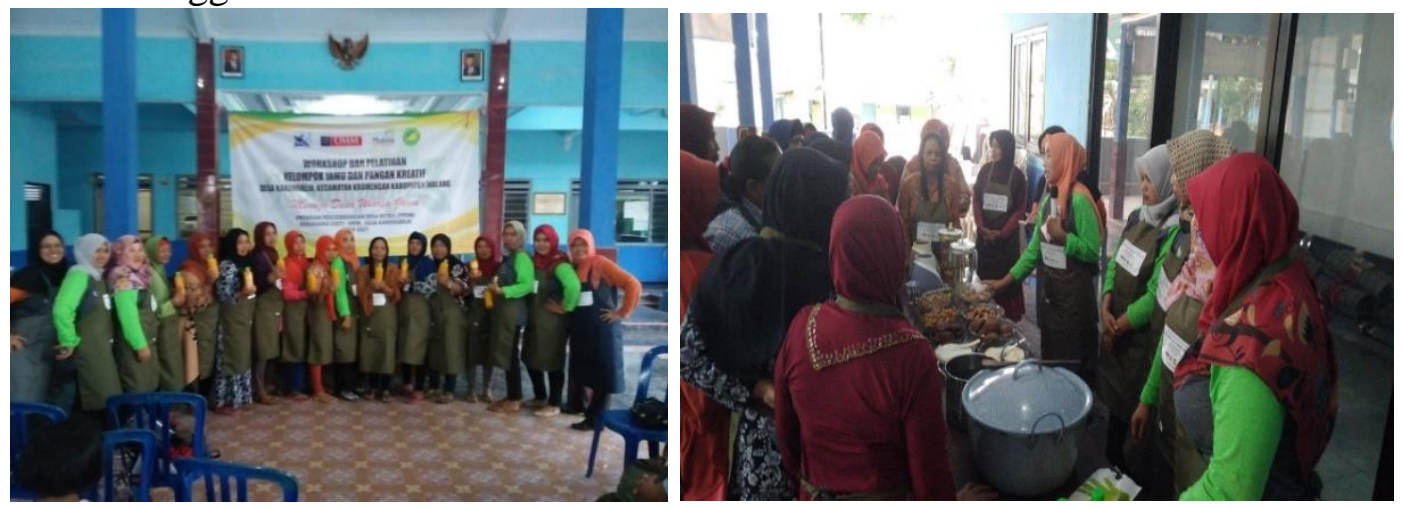

Gambar 12: pelatihan dan pendampingan produksi jamu yang hygienis dan aman 
Proses produksi yang sangat menyita waktu serta tidak higienis juga disebabkan karena rata-rata pengrajin masih menggunakan alat tradisonal berupa lumpang dan alu, sehingga dalam pendampingan ini, tim Pengabdian UMM juga menyerahkan bantuan 10 Blender kepada BUMDes sekaligus sebagai modal usaha BUMDes untuk disalurkan kepada pengrajin dengan sistem pembelian yang mudah dan murah.
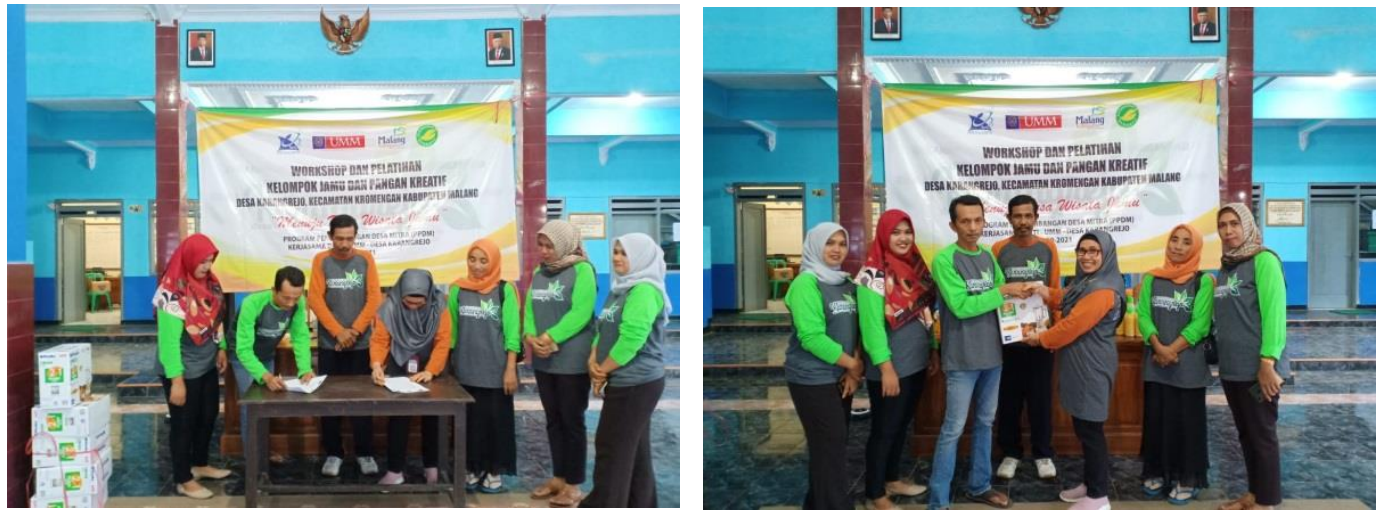

\section{Gambar 13 proses serah terima alat blender kepada BUMDes untuk membantu mempercepat produksi dan menjaga hygienitas jamu}

G. Pembuatan website untuk konsep pengembangan jamu dan pangan kreatif berbasis masyarkat..

Tim PengabdianUMM juga memberikan peluang bagi pemasaran online dengan mulai mengenalkan warga di luar Karangrejo tentang jamu produksi Karangrejo yang hygienis dan berkualitas. Pemasaran online tidak terbatas melalui web blog saja tetapi juga bisa melalui Facebook, Instagram dan lain-lain. Media sosial ini menjelaskan kepada publik tentang organisasi, produk yang dihasilkan juga kegiatan-kegiatan rutin yang dilakukan oleh paguyuban. No kontak juga disertakan untuk memudahkan aset penjualan jamu ke luar desa Karangrejo. Kemudahan untuk mengetahui hasil pemasaran dapat diakses melalui alamat : https://paguyubanjamu.blogspot.com/. Web blog ini akan selalu disempurnakan sesuai dengan kebutuhan yang akan datang.

\section{KESIMPULAN}

Proses pendirian desa wisata jamu Karangrejo merupakan upaya yang harus terus menerus dan dinamis melalui pendekatan formal maupun informal, dengan berbagai sektor disertai strategi pendampingan berupa pelatihan dan peningkatan kualitas sumber daya mitra, workshop dan tindak lanjut pendampingan terhadap SDM sebagai persiapan menjadi desa wisata, serta publikasi melaui web dan pembuatan pintu gerbang selamat datang sebagai tonggak dimulainya semangat baru membangun desa wisata Jamu dan Pangan kreatif.

\section{DAFTAR PUSTAKA}

Rencana Pembanguna Jangka Menengah Desa (RPJMDes) tahun 2017-2011 Desa Karangrejo Kecamatan Kromengan Kabupaten Malang.

Anwar, Y., 2012, 19 Inspirasi Bisnis Minuman dan Snack, Agromedia, Jakarta 
Anwar. Y., (2010). Inspirasi Usaha Makanan Minuman untuk Home Industry Modal di Bawah 5 Juta. Agromedia, Jakarta.

Setyo. E., (2006). Membuat aneka olahan Pisang, Bisnis yang menjanjikan. Agromedia. Jakarta

Rahmat Rukmana. (2001). Aneka olahan limbah tanaman pisang,jambu mete dan Rosella. Kanisius. Jogjakarta: Kanisius 